مقاله يزوهشى

مطالعه يتانسيل دَر آسيبى تر كيب فنلى حاصل از عصاره متانولى علفهرز سوروف بر صفات جوانهزنى و رفتارهاى سيتوزنتيك برنج (Echinochloa crus-galli)

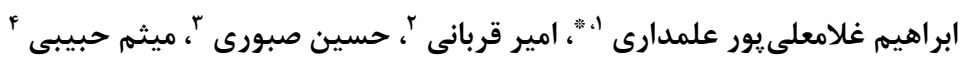

جكيده مبسوط

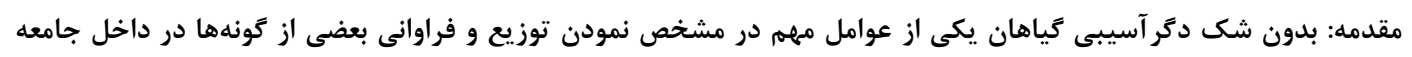

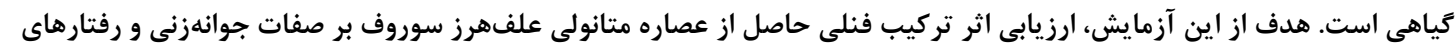
سيتوزنتيك برنج است.

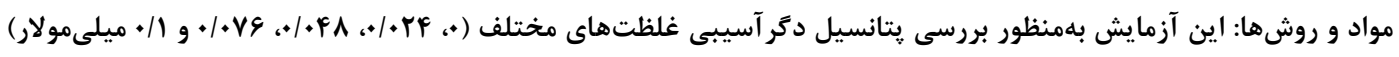

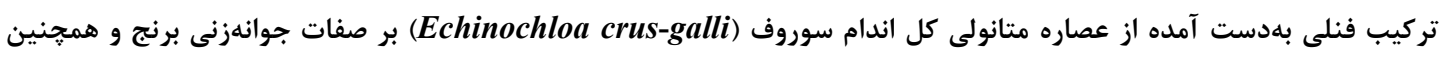

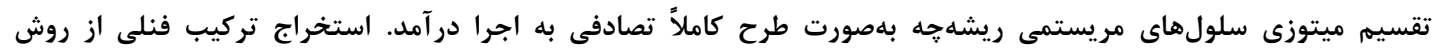

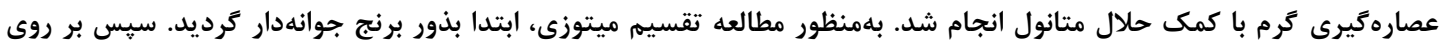

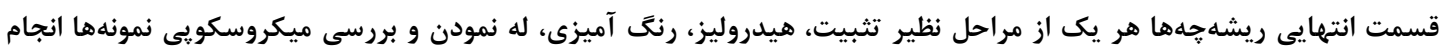

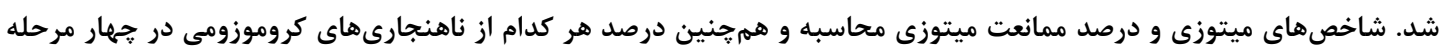

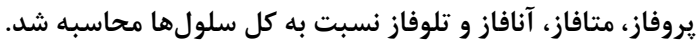

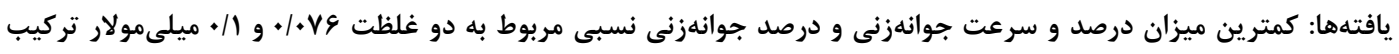

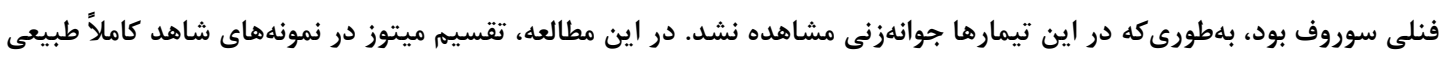

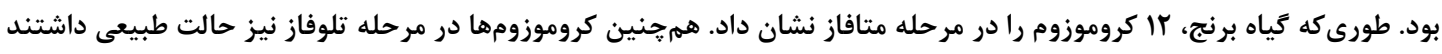

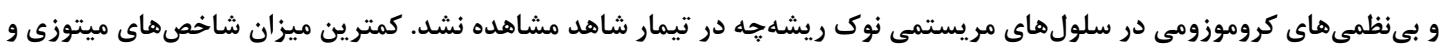

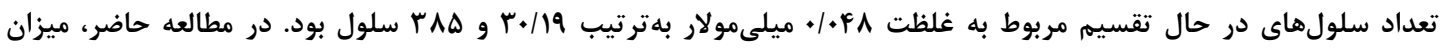

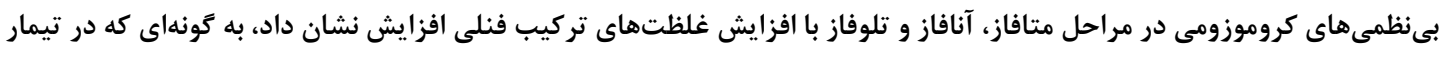

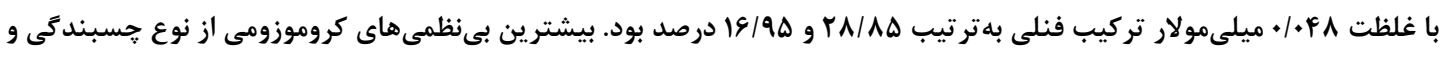

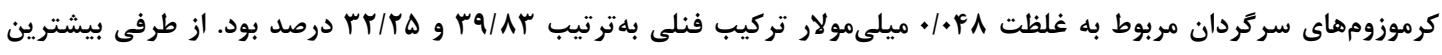

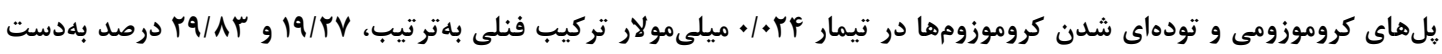

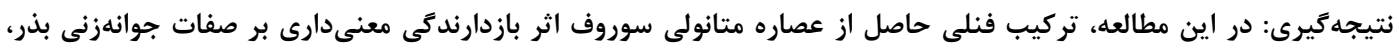

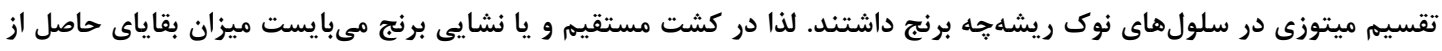

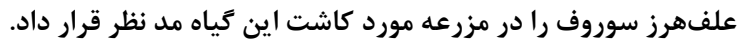
وازمهاى كليدى: بيىنظمىهاى كروموزومى، يلهاى كروموزومى، تركيب فنلى، درصد جوانهزنى نسبى جنبه هاى نو آورى: ا-تفاوت در تاثير غلظتهاى مختلف تركيب فنلى حاصل از عصاره متانولى علفهرز سوروف بر جوانهزنى و كاهش رفتارهاى سيتوزنتيك برنج

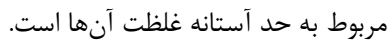
ז-كاشت ارقام مقام برنج در كشت مستقيم و يا در شرايط خزانه به تركيبات دَّرآسيب بقاياى علفهرز سوروف ييشنهاد مى گردد.

http://dorl.net/dor/20.1001.1.23831251.1399.7.1.8.5 استاديار كروه توليدات كياهى دانشكده كشاورزى و منابع طبيعى

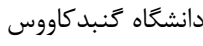

http://dx.doi.org/10.29252/yujs.7.1.67

CrossMark

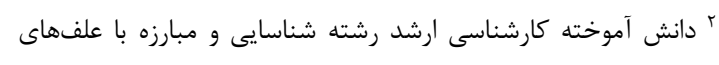

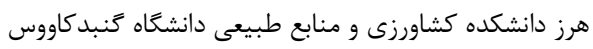

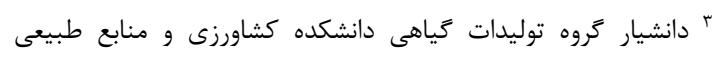
دانشكاه كنبد كاووس † مربى كروه زيست شناسى دانشكاوسه علوم يايه دانشكاه كنبد كاووس 
تاكنون بيش از . .... متابوليت ثانويه شناسايى

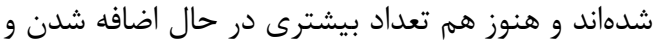

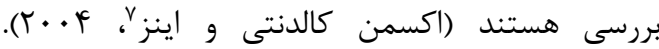

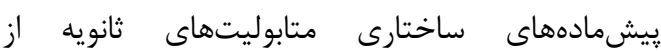

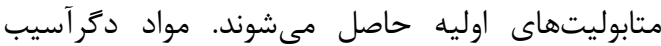
ترشح شده از اندامهاى مختلف يك كونه كياهى نه تنهاي

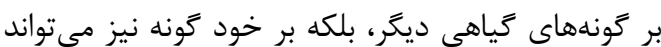

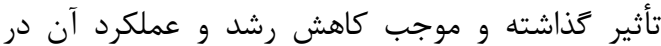

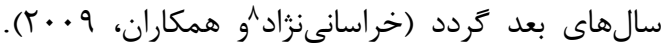
اصولاً تركيبات شيميايى، بهخصوص تركيبات ثانويه، با بانئ دارا بودن اثر دكرآسيبى آللوكميكال ج ناميده مي شيوند

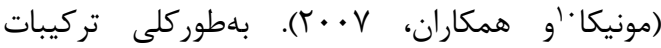

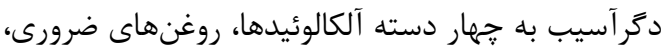
كليكوزوئيدها و غيره نظير فنلها، اسيدهاى آلى و ديكر

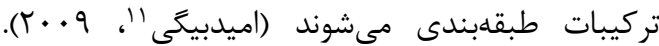
بيش از ... نوع تركيبات فنلى از محصولات كياهى مختلف استخراج شده است كه شامل فلاونوئيدها، اسيدهاى فنلى، كومارينها و تاننهاست كه هر تروه به

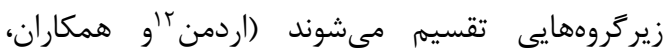

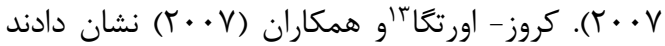

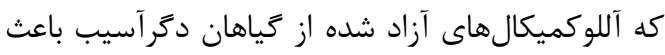
افزايش انواع اكسيرن واكنشكر در كياهان يذيرنده و در آندان نتيجه فعال شدن يا تغيير در نحوه فعاليت آنزيمهاى آنتىاكسيدان مىشوند. تركيب فنلى از تركيبات موثر در بديده دكرآسيبى هستند كه در ساختمان شيميايى خود

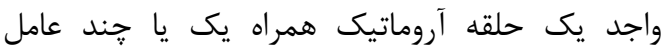

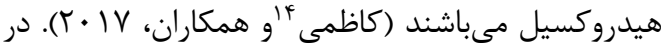

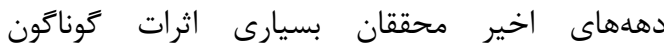

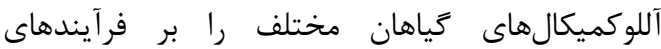
فيزيولوزيكى و بيوشيميايى كزارش كردهاند (عبدو رئوف

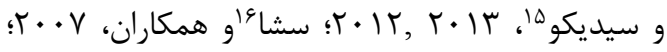

\footnotetext{
${ }^{7}$ Oksman-Caldentey and Inzé

${ }^{8}$ Khorasani Nezhad

${ }^{9}$ Allelochemicals

${ }^{10}$ Monica

${ }^{11}$ Omidbeigi

${ }^{12}$ Erdman

${ }^{13}$ Cruz- Ortega

${ }^{14}$ Kazemi

${ }^{15}$ Abdul Rauf and Siddiqui

${ }^{16}$ Setia
}

مقدمه

برنج با نام علمى Oryza sativa L. بعد از گَندم مهمترين محصول كشاورزى جهان است و نقش مهمى در تغذيأ بيش از نيمى از جمعيت جهان دارد. • 9 درصد سطح زير كشت جهانى برنج در آسيا قرار دارد. همخام با افزايش جمعيت، توليد جهانى برنج نياز به افزايش قابل توجهى در ·ـ •إل سال بعدى دارد

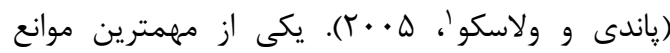
زيستى در توليد برنج، علفهاى هرز هستند كه بخش

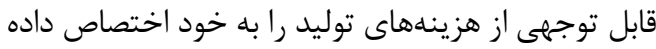

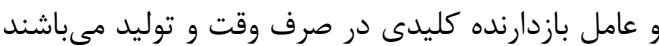

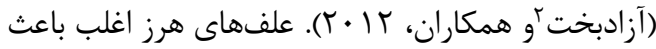

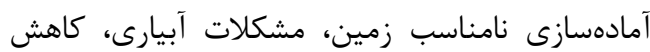
حاصلخيزى خاى و مديريت محصول مىشوند (رودنبرى

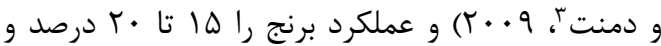
در موارد شديدتر تا بيش از • ه درصد، بسته به كونه و

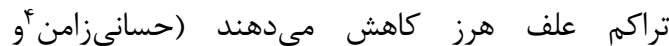

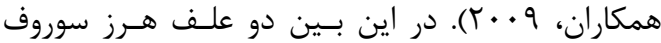
Echinochloa crus-galli (L.) Beauv) بهنوان مهمترين علفهاى (Cyperus diformis L.) هرز مزارع بـرنج محسـوب شـده و خـسارت قابــل

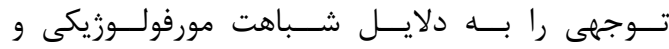
اكولوزيكى كه با برنج دارند به اين گياه وارد مىسازند.

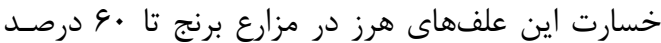

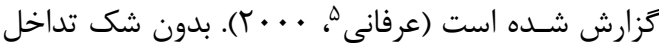
مواد دكرآسيب يكى از فاكتورهاى مهرم در مشخص نمودن توزيع و فراوانى بعضى از گونهها در داخل جامعه كَياهى است. در حقيقت كاهش عملكرد گياهان زراعى تونى توسط علفهاىهرز مىتواند نتيجه مستقيم رقابت و دكرآسيبى و يا فعاليت توام آن دو با هم باشد (كيديولو

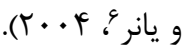
برخى از زياهان گروه بزرگ و متنوعى از تركيبات آلى بهنام متابوليتهاى ثانويه را توليد مى كنند، طورى كه

\footnotetext{
${ }^{1}$ Pandey and Velasco

${ }^{2}$ Azadbakht

${ }^{3}$ Rodenburg and Demont

${ }^{4}$ Hasanuzzaman

${ }^{5}$ Erfani

${ }^{6}$ Kadiolu and Yanar
} 
(تقسيم ميتوز) بذر باقلا را بررسى نمودند. نتايج آنها نشان داد كه شاخص ميزان جوانهزنى، رشد كياهجهاى و شاخص ميتوزى با افزايش غلظت تركيب يارتنين،

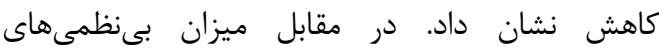
كروموزومى افزايش يافت.

علفهرز درجه اول برنج، گياه سوروف است و و مشكلات جدى را براى برنجكاران در سالهاى اخير درن ايجاد نموده و كشاورز بهدليل وجود تهاجم اين علفهرز

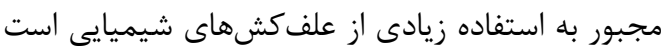
كه اين امر موجب شكل بكيرى بيوتيیٍهاى مقاوم و آلودگى شديد محيط زيست مى گردد. بنابراين جستجو و توسعه علفكشهاى جديد از زياهان داراى توان دَر آسيبى روشى مؤثر جهت توليد علف كشها با منشاء زيستى و يا كنترل زيستى علفهاى هرز است كه بـ با شناسايى توان دكرآسيبى گياهان آغاز مىشود. از طرفئي ديخر با توجه به تحقيقات انجام شده، عصاره متانولى علفهرز سوروف داراى حداكثر قابليت در استخراج متابوليت ثانويه فنل نسبت به بهوري ساير حلالها است

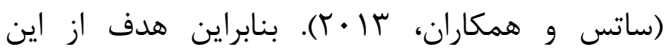
آزمايش، ارزيابى اثر تركيب فنلى حاصل از عصاره متانولى علفهرز سوروف بر صفات جوانهزنى و رفتارهاى إنى سيتوزنتيك برنج در كشت مستقيم و يا در شرايط خزانه

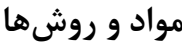
شرايط اقليمى وجغرافيايى محل جمع آورى نمونههاى علفهاىهرز، شناسايى و آمادهسازى آنها اين آزمايش براى ارزيابى توانايى د دَرآسيبى غلظتهاى مختلف تركيب فنلى حاصل از عصاره متانولى علفهرز سوروف (Echinochloa crus-galli) بر مجنائ صفات جوانهزنى برنج و اثر آنها بر تقسيم ميتوزى

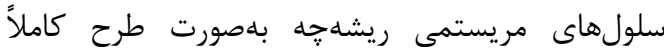

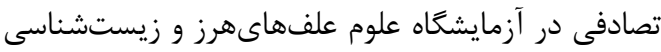

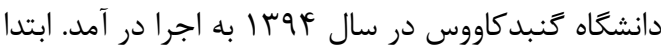
نمونههاى علفهرز سوروف در نيمه اول ارديبهشت از

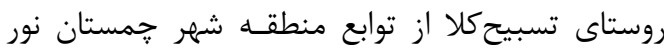

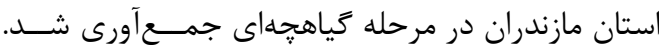

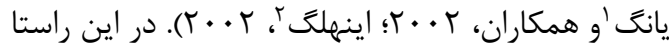
تاكنون تحقيقات مختلفى در مورد شناسايى و ارزيابى

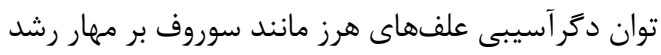

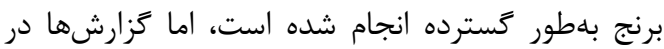
مورد اثرات آللوكميكال ها از جمله تركيب فنلى حاصل از عصاره آلى سوروف بر سيتولوزى گياهان بلويزه برنج

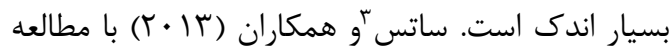
غربالخرى تركيبات يلى فنلى عصارههاى آلى علفهرز سوروف (Echinochloa crusgalli Roxb) بdوسيله روشهاى كروماتوكرافى، ززارش نمودند كه عصاره متانولى اين علفهرز از بيشترين مقدار فنل كل (SV|•

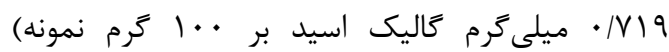
برخوردار بود. 11 تركيب در عصاره علفهرز سوروف بلوسيله روشهاى كروماتوگرافى مورد شناسايى قرار

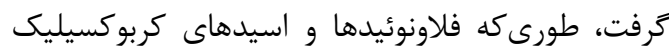
فنلى از مهمترين اين تركيبات بودند. تحقيقات

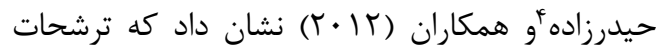
ريشه حاصل از سوروف اثر فيتوتوكسى روى ارقام برنج دارد.

سيتوزنتيك علمى است كه از تركيب سيتولوزى و

زنتيك بلوجود آمده است. اين علم شامل كار با كروموزومها (روشهاى رنغَآميزى كروموزومها)، عمل و حركت كروموزومها (تقسيم سلولى ميتوزى و ميوزى)، تعداد و ساختمان كروموزومها (تجزيه كاريوتايڤ) و و تغييرات متعدد ساختمانى و رفتارهاى مربوط به

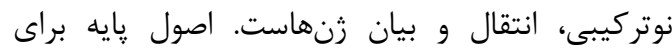

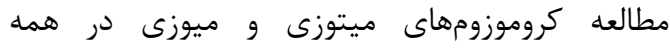
كَنههاى گياهى مشابه بوده و شامل جمع آورى نمونهها،

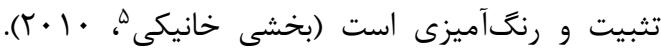

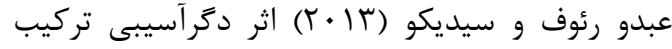
سمى يارتنين (جزء دسته ترينوئيدها) استخراج شده از كونه علفستارهاى (Parthenium hysterophorus)

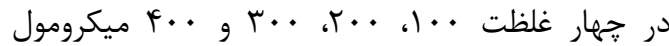

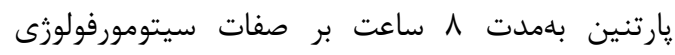

\footnotetext{
1 Yang

${ }^{2}$ Einhellig

${ }^{3}$ Sathis

${ }^{4}$ Heidarzade

${ }^{5}$ Bakhshi Khaniki
} 
Biochrom libera-S 22 خوانده شد. در نهايت، ميزان فنل كل بر حسب ميلى ترم

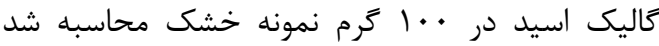

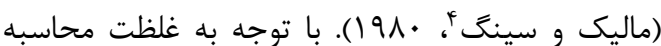

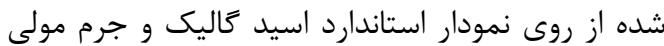

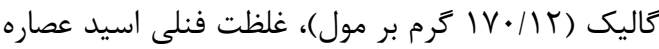

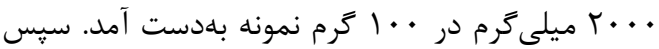

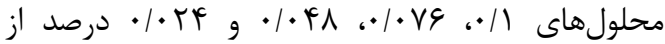

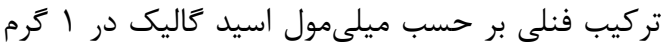
نمونه خشك محاسبه كرديد. متانول موجود در عصاره از طريق تفاوت نقطه جوش خارج كرديد، طورىكه نقطه جوش متانول و فنل بلترتيب 9D و 11/V درجه

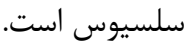

\section{آزمايشهاى جوانهزنى}

ابتدا بذرهاى خشك و سالم برنج با هييوكلريت

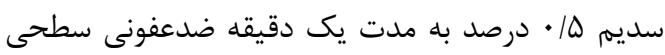
كرديد، سيس بلهطور كامل با آب مقطر شستشو داده شد. بذرها به مدت ^ ماعت در لولههاى آزمايش حاوى باى

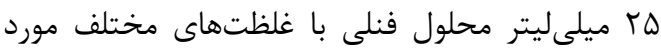
بررسى خيسانده شدند. نمونه شاهد در آب مقطر تيمار شد. هر غلظت شامل · · أعدد بذر بودند. در مرحله بعد تمام بذرهاى مربوط به هر تيمار سه بار با آب مقطرشستشو داده شد. بذرها در كاغذ صافى مرطوب و ونا باري در يترى با قطر ها سانتىمتر قرار داده شد. هر تيمار با داء

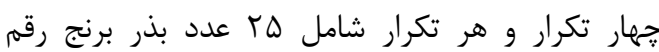
دمسياه بود. يترىهاى حاوى بذر در اتاقى رشد و در در

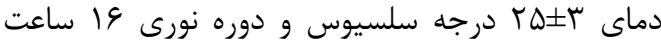

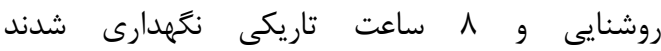

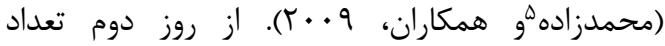
بذرهاى جوانهزده در هر روز تا روز هفتم مورد شمارش قرار كرفت. سيس در انتهاى روز هفتهم صفات ذيل مورد درد

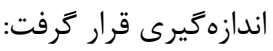

براى محاسبه درصد جوانهزنى، بذور جوانهزدها با ريشه بلندتر از دو ميلىمتر شمارش شدند (هاردكرى و

${ }^{4}$ Malick and singh

${ }^{5}$ Mohammadzadeh
در ابتـــدا نمونه كياهى مورد بررسى با كمك فلـور

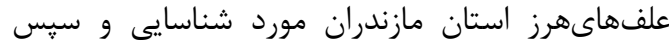
جهت برداشـتن ترد و غبار با آب مقطر بـراى مـدات كوتـاهى مـورد شستشو قرار ترفت. نمونههاى كياهى بردي

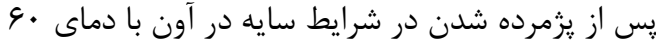

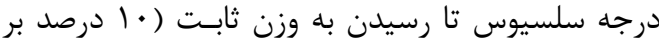

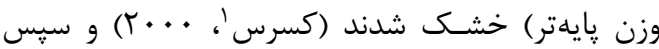

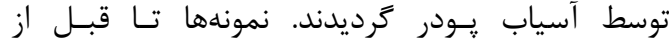
اسـتفاده در كيسـههاى پِلاسـتيكى نكهدارى شـــند.

\section{استخراج تركيب فنلى از عصاره متانولى علفهرز

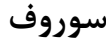

براى استخراج تركيب فنلى از روش عصارهكيرى كرم استفاده شد. با توجه به اينكه عصاره آلى متانولى آلى روتي علفهرز سوروف داراى حداكثر قابليت استخراج تركيب فنلى نسبت به ساير حلالها است (ساتس و همكاران،

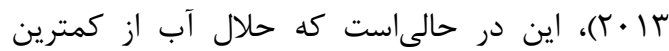

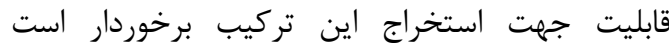

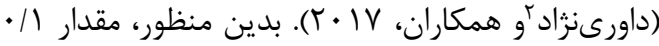

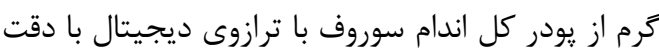

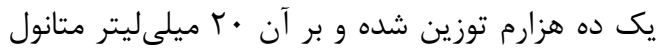

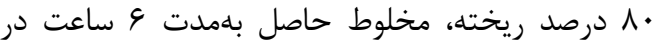

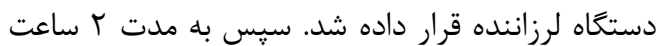

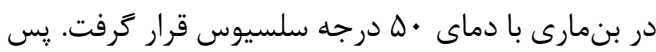
از كذشت اين مدت، عصارهها توسط كاغذ صافى فيلتر و

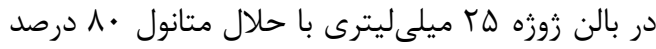

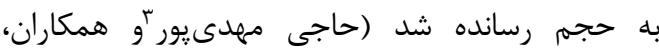

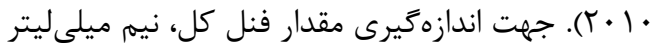

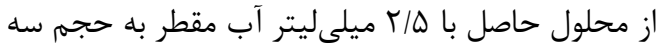
ميلىليتر رسانده شد، سيس روى محلول بهدست آمده

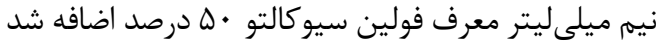

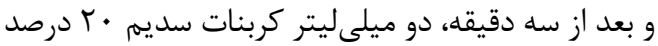

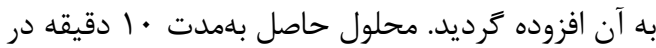
حمام آب جوش قرار داده و پس از سرد شدرد شدن، ميزان جذب نورى بلوسيله دستگاه اسيكتروفتومتر با مدل

\footnotetext{
${ }^{1}$ Caceres

${ }^{2}$ Davarynejad

${ }^{3}$ Haji Mehdipour
} 
ريشهُجه بهطول تقريبى ه/ • تا ا سانتىمتر بود. سِّ جهت مطالعه، مر احل بهشرح ذيل انجام شد.

\section{تثبيت \& سلولها و محتويات آنها}

بلمنظور حفظ و نكادارى اشكال سلولها و محتويات آنها از جمله كروموزومها و ممانعت از تغييرات احتمالى

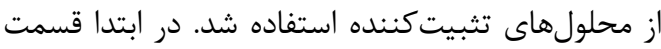

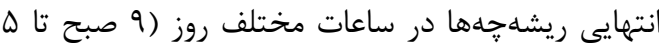
بعد از ظهر) قطع و در محلول ^- هيدروكسى كينولين

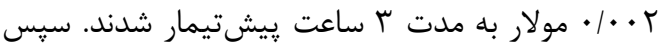

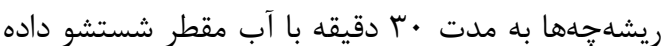
و سيس وارد محلول تثبيتكننده شد. براى تثبيت از

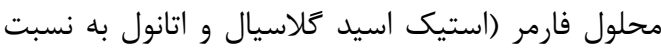
يك به سه) بلمدت (است سF ساعت استفاده شد.

\section{نكَدهارى ₹ مر يستم انتهايى ريشهجه}

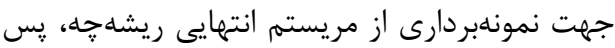
از خارج كردن از محلول تثبيت كننده فارمر، با آب مقطر آندر קند مرتبه شستشو و آب اضافى ريشهاههها با كاغذ

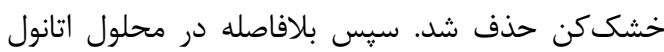
• ل درصد قرار داده و در دماى جهار تا ينج درجه سلسيوس در يخجال نغَدارى شد. اين امر جهت

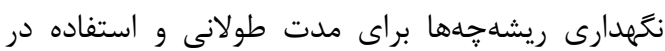
فرصت مناسب صورت كرفت.

له و نرم كردن بافت مريستم انتهايى ريشه

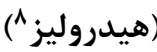

بدين منظور پِ از خارج كردن ريشه

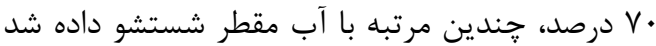
و سيس در محلول هيدروليز كننده اسيد هيدروكلريك يك نرمال قرار داده و در نهايت با كمك خراغ تراغ الكلى در دماى •4 درجه سلسيوس بهمدت •إد دقيقه حرارت داده شد. ريشه קهها پِ از از انتقال به اسيد هيدروكلريك

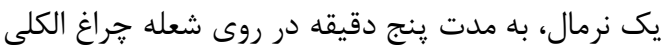

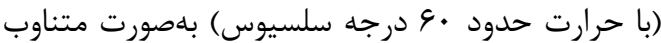

${ }^{6}$ Fixation cells

${ }^{7}$ Storage

${ }^{8}$ Hydrolysis

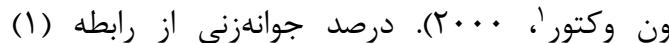
محاسبه شد

رابطه ):

$$
\mathrm{GP}=\frac{\sum_{i=0}^{n} \mathrm{ni}}{\mathrm{N}} \times 100
$$

در اين رابطه n تعداد بذرهاى جوانه زده و N تعداد كل بذرهاى كشت شده است.

جهت اندازهيرى سرعت جوانهزنى، از روز دوم آزمايش تعداد بذرهاى جوانهزده بلصورت روزانه تا روز

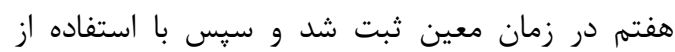

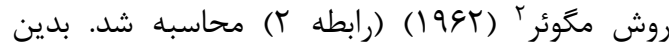
صورتكه در آن Ni تعداد بذرهاى جوانهزده در هر روز و

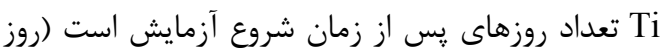

$$
\text { رابطه r }
$$

درصد جوانهزنى نسبى از رابطه بَ محاسبه شد (رو و رابطه ז: در اين رابطهRG: درصد جوانهزنى نسبى،TGS: تعداد بذرهاى جوانهزده تيمار،

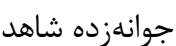
محاسبه درصد ممانعت از جوانهزنى بذره ه با استفاده

$$
\begin{aligned}
& \text { ز رابطه fأ برآورد شد. } \\
& \text { رISG }=\frac{\mathrm{R} 2-\mathrm{R} 1}{\mathrm{R} 1} \times 100 \quad \text { ابطه }
\end{aligned}
$$

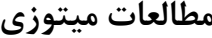

بامنظور بررسى اثر غلظتهاى مختلف عصاره متانولى حاصل از علفهرز سوروف بر رفتئ رفتارهاى سيتوزنتيك برنج (رقم دمسياه)، ابتدا بذرهاى برنج جوانهدار گرديده است. ملاك جوانهزنى، ظهور جزئى الماني

\footnotetext{
${ }^{1}$ Hardgree and Van Vactor

${ }^{2}$ Maguire

${ }^{3}$ Relative Germination Percentage

${ }^{4}$ Rho and Kil

${ }^{5}$ Percentage Inhibition in Seed Germination
} 


$$
\begin{aligned}
& \text { رابطه ه: }
\end{aligned}
$$

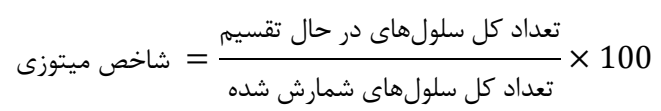

$$
\begin{aligned}
& \text { رابطه 9: }
\end{aligned}
$$

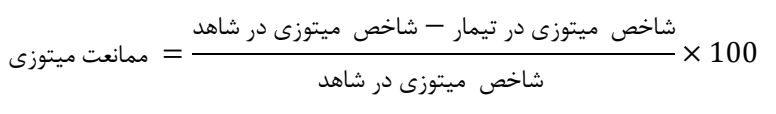

$$
\begin{aligned}
& \text { درصد هر كدام از ناهنجارىهاى كروموزومى در }
\end{aligned}
$$

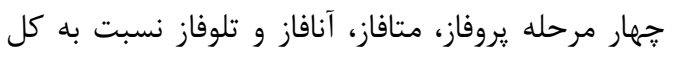

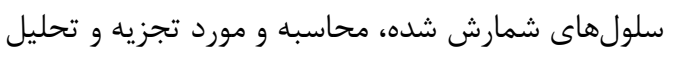

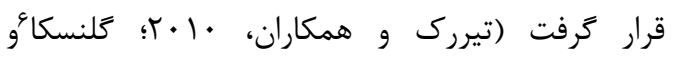

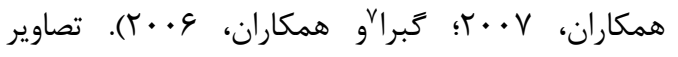

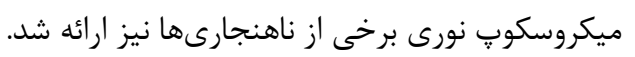

\section{تجزيه و تحليل دادهها}

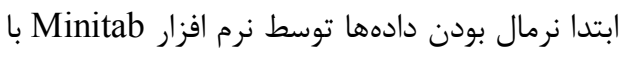

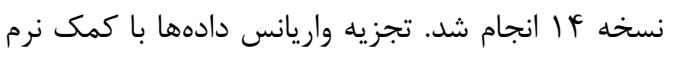

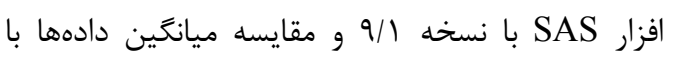

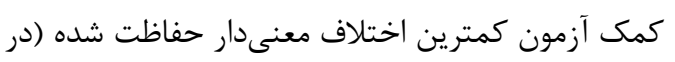

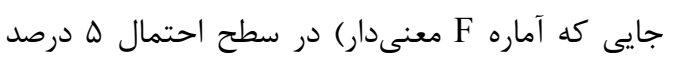

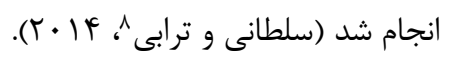

\section{نتايج و بحث}

نتايج حاصل از اثر غلظتهاى مختلف تركيب فنلى حاصل از عصاره متانولى علفهرز سوروف بر إن صفات جوانهزنى بذر برنج:

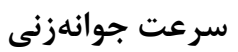

نتايج نشان داد كه تيمارهاى مختلف تركيب فنلى سوانى

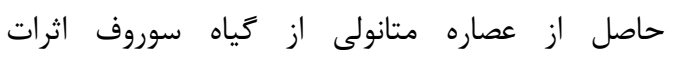

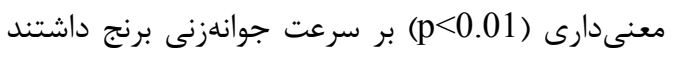

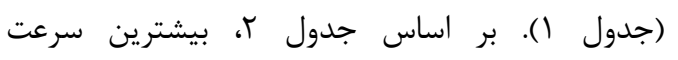

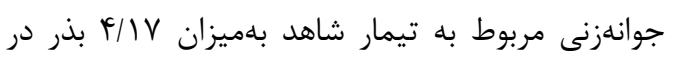

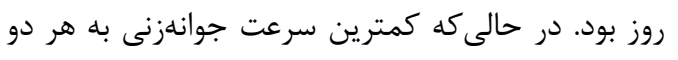

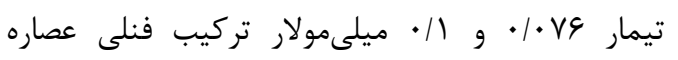
متانولى علفهرز سوروف بود، طورى كه در اين تيمارها

${ }^{6}$ Glin'ska

${ }^{7}$ Gabara

${ }^{8}$ Soltani and Torabi
حرارت داده شدند. بايد دقت نمود كه اسيد

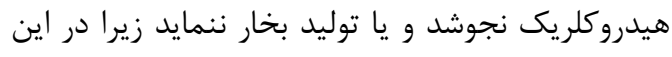

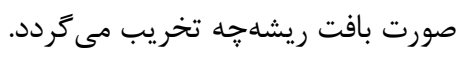
رنى آميزى ' منطقه مريستمى نوك ريشه ريشه

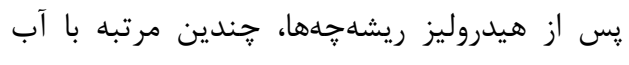

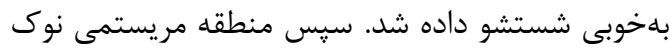

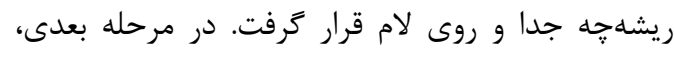

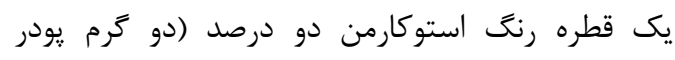

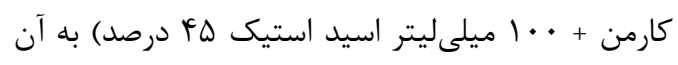
اضافه شد.

له نمودن ' نمونه جهت يخش سلولها در يك سطح

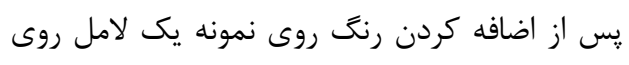

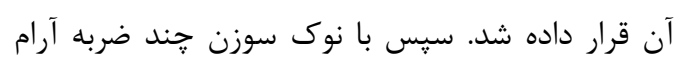

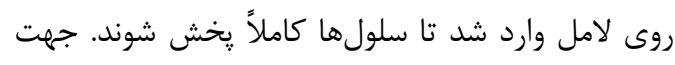

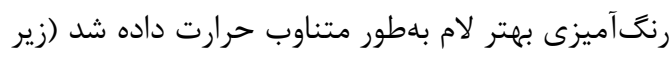

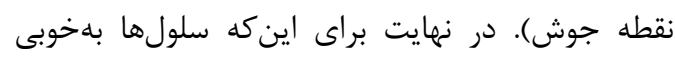

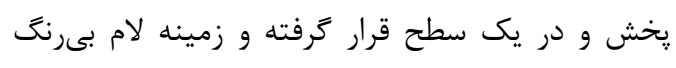

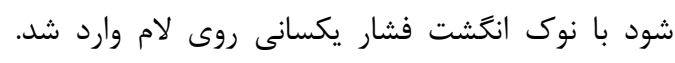

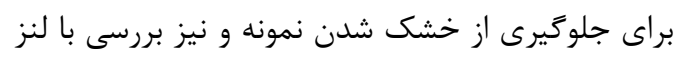

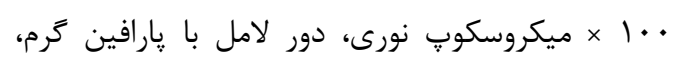

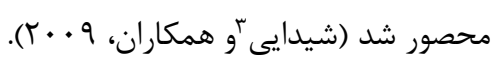

\section{بر رسى ميكروسكويى}

از اسلايدهاى تهيه شده ميكروسكوبى ميكروسكوب نورى دمل Olympus ديجيتال Canon مدل G6 عكسبردارى و مطالعه انجام

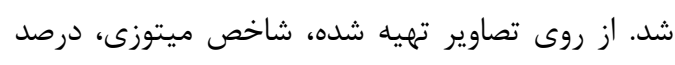

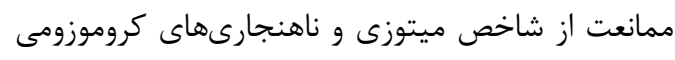

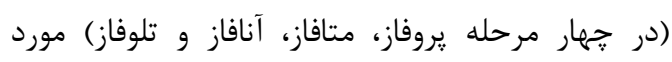
بررسى قرار خرفت. شاخص ميتوزى و درصد ممانعت مرفت ميتوزى طبق

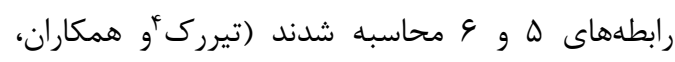

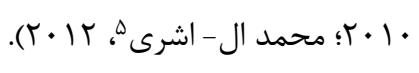

\footnotetext{
${ }^{1}$ Staining

${ }^{2}$ Squashing

${ }^{3}$ Sheidai

${ }^{4}$ Teerarak

${ }^{5}$ Mohamed and El-Ashry
} 
و كوئينونها بهعنوان مهمترين مواد دكرآسيب مطرح

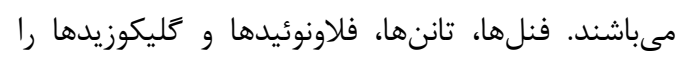

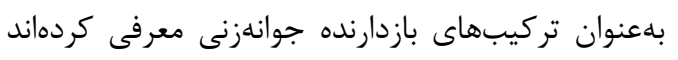

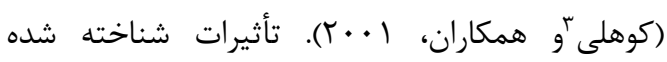

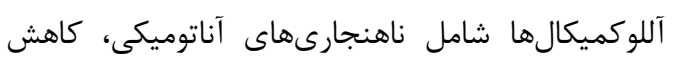

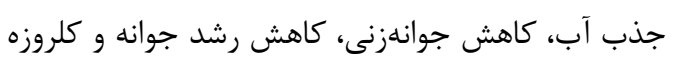

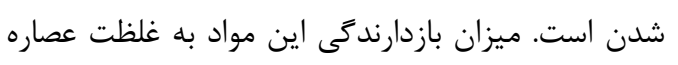

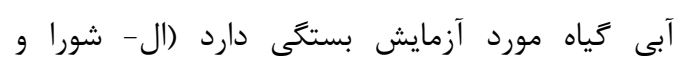

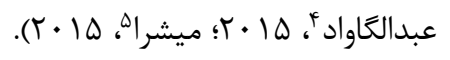

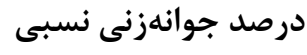

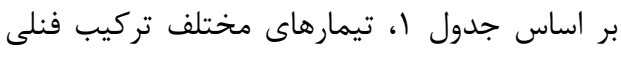

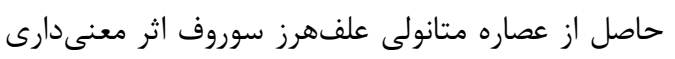

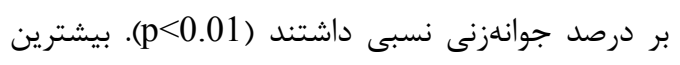

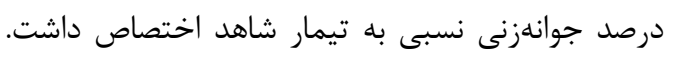

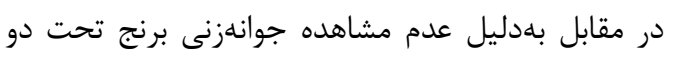

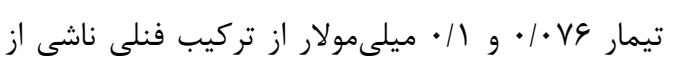
عصاره متانولى علفهرز سوروف، اين ميزان صفر تزارش

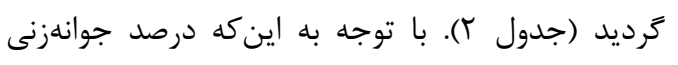

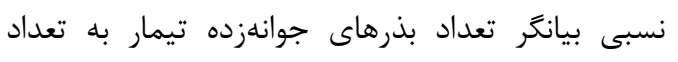

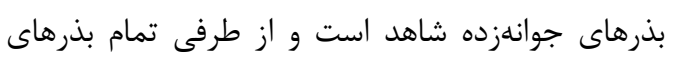
كشت شده در نمونه شاهد جوانهزدند، بنابراين مى تونان استباط نمود كه بذرهاى برنج مورد مطالعه از كيفيت

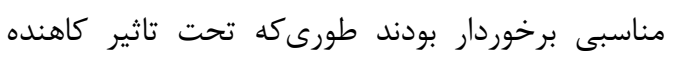

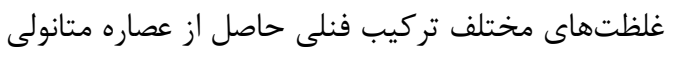
علفهرز سوروف قرار خرفتند.

${ }^{3}$ Kohli

${ }^{4}$ El- Shora and Abd El- Gawad

${ }^{5}$ Mishra
جوانهزنى مشاهده نشد.

\section{درصد جوانهزنى}

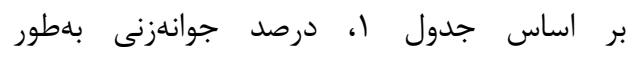
معنى دارى تحت تاثير غلظتهاى مختلف تركيب فنلى

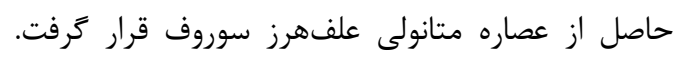

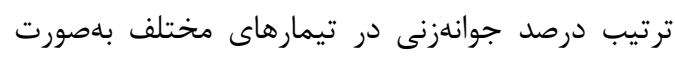

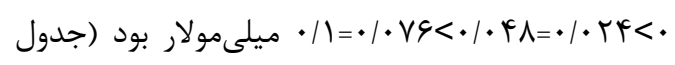
r). اين نتيجه را مىتوان اين كَونه توجيه نمود كه

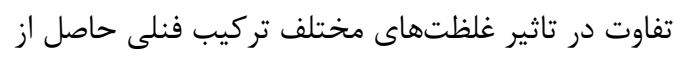

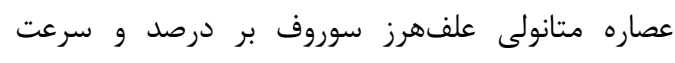

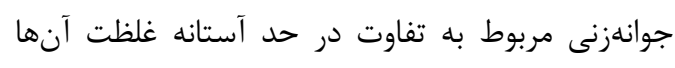

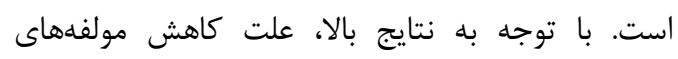
جوانهزنى برنج مىتواند افزايش ميزان تركيب فنلى در باري

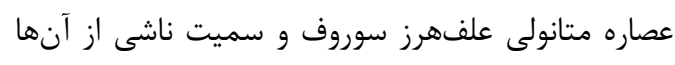
باشد. البته ممكن است كه مولفههاى يتانسيل اسمزى عارى

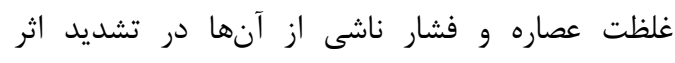

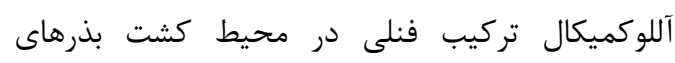

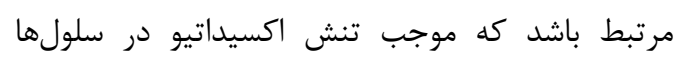

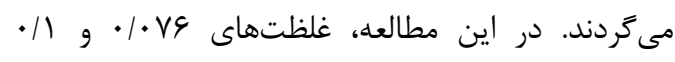

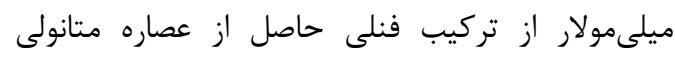

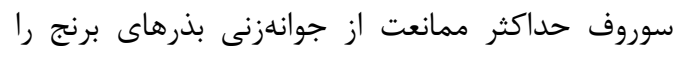

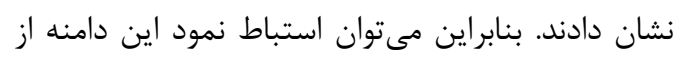

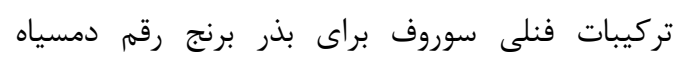

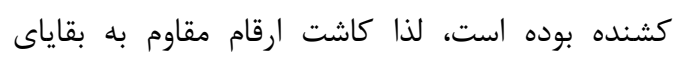

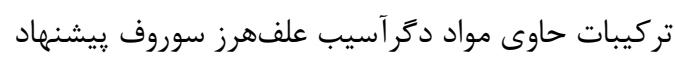

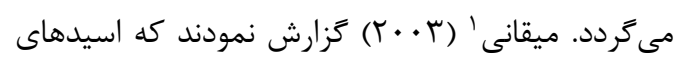

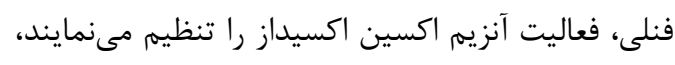

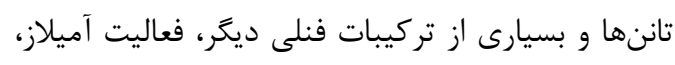

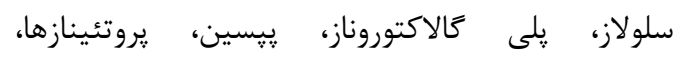

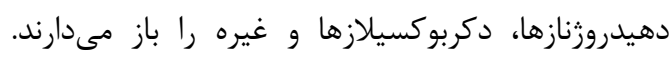

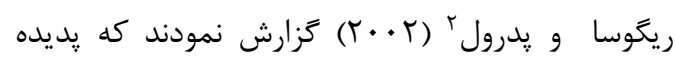

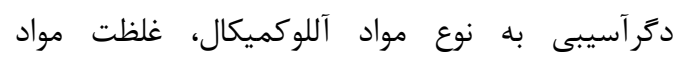
آللوشيميايى و حساسيت كياه هدف بسيار وابسته است. در ميان آللوكميكالها تركيبات حلقوى نظير فنلها،

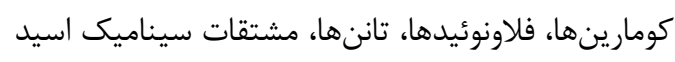

\footnotetext{
${ }^{1}$ Mighani

${ }^{2}$ Regosa and Pedrol
} 
جدول ا. تجزيه واريانس (ميانگَن مربعات) اثر غلظتهاى مختلف تركيب فنلى حاصل از عصاره متانولى علفهرز سوروف بر صفات جوانهزنى برنج

Table 1. Analysis of variance (mean square) for different concentrations of the phenolic compound obtained from the methanol extract of E. crus-galli on seed germination traits of rice

\begin{tabular}{|c|c|c|c|c|}
\hline $\begin{array}{l}\text { منابع تغييرات } \\
\text { S.O.V }\end{array}$ & $\begin{array}{c}\text { درجه آزادى } \\
\text { df }\end{array}$ & $\begin{array}{c}\text { درصد جوانهزنى } \\
\text { Germination percentage }\end{array}$ & $\begin{array}{c}\text { سرعت جوانهزنى } \\
\text { Germination rate }\end{array}$ & $\begin{array}{c}\text { درصد جوانهزنى نسبى } \\
\text { Relative germination } \\
\text { percentage }\end{array}$ \\
\hline تيمار Treatment & 4 & $15.04^{\text {*** }}$ & $1.874^{* * * *}$ & $15.04^{* * *}$ \\
\hline خطا Error & 15 & 0.0104 & 0.0109 & 0.0104 \\
\hline $\begin{array}{c}\text { ضريب تغييرات (.) } \\
\text { Coefficient of variance (\%) }\end{array}$ & - & 5.460 & 23.44 & 5.460 \\
\hline
\end{tabular}

**: indicates significant at $1 \%$ confidence level

جدول r. مقايسه ميانكَين اثر غلظتهاى مختلف تركيبات فنلى حاصل از عصاره متانولى علفهرز E. crus-galli بر صفات جوانهزنى برنج

Table 2. Mean comparison of different concentrations of the phenolic compounds obtained from the methanol extract of E. crus-galli on seed germination percentage of rice

\begin{tabular}{|c|c|c|c|c|}
\hline $\begin{array}{c}\text { غلظتهاى فنلى (ميلىمولار) } \\
\text { Phenol concentrations } \\
\text { (mM) }\end{array}$ & $\begin{array}{c}\text { درصد جوانهزنى } \\
\text { Germination } \\
\text { percentage }\end{array}$ & $\begin{array}{c}\text { سرعت جوانهزنى (بذر در روز) } \\
\text { Germination rate } \\
\text { (Seed/day) }\end{array}$ & $\begin{array}{c}\text { درصد جوانهزنى نسبى } \\
\text { Relative } \\
\text { germination } \\
\text { percentage }\end{array}$ & $\begin{array}{l}\text { درصد ممانعت از جوانهزنى بذر } \\
\text { Percentage inhibition } \\
\text { in seed germination }\end{array}$ \\
\hline $\mathrm{T} 1$ & $100^{\mathrm{a}}$ & $4.170^{\mathrm{a}}$ & $100^{\mathrm{a}}$ & 0 \\
\hline $\mathrm{T} 2$ & $10.25^{\mathrm{b}}$ & $0.4175^{b}$ & $10.25^{\mathrm{b}}$ & 89.75 \\
\hline $\mathrm{T} 3$ & $9.50^{\mathrm{b}}$ & $0.290^{\mathrm{b}}$ & $9.50^{\mathrm{b}}$ & 90.50 \\
\hline $\mathrm{T} 4$ & $0.00^{\mathrm{c}}$ & $0.00^{\mathrm{c}}$ & $0.00^{\mathrm{c}}$ & 100 \\
\hline T5 & $0.00^{\mathrm{c}}$ & $0.00^{\mathrm{c}}$ & $0.00^{\mathrm{c}}$ & 100 \\
\hline LSD5\% & 0.1539 & 0.1574 & 0.1539 & - \\
\hline
\end{tabular}

ميانكينهاى داراى حروف متفاوت در هر ستون، از نظر آمارى در سطح احتمال ه درصد اختلاف معنى دارى دارند (PLSD) Means with non-similar letters at each column are significantly different at 5\% confidence level using PLSD test

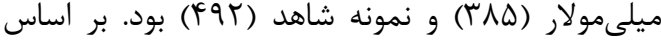

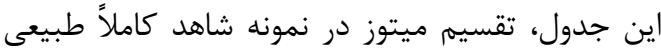
بود. گياه برنج rا كروموزوم را در مرحله متافاز نشان

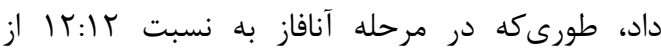
يكديكر جدا شدند. همجنين تيمار شاهد در در مرحله تلوفاز نيز از روند طبيعى برخوردار بود و بىنظمىهاى كروموزومى در سلولهاى مريستمى نوى ريشه

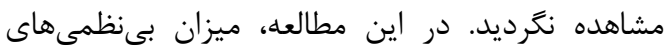

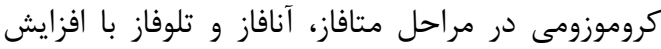
غلظتهاى تركيب فنلى حاصل از عصاره متانولى افزايش

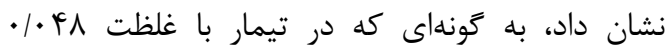

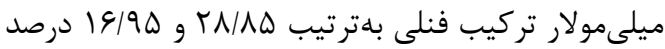

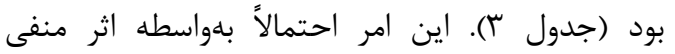

ميزان بىنظمىهاى كروموزومى در تقسيم ميتوز تحت غلظتهاى مختلف تركيب فنلى حاصل از عصاره متانولى علفهرز سوروف نتايج بهدستآمده از تجزيه و تحليل سيتوزنتيكى نشان داد كه تركيب فنلى حاصل از عصاره متانولى سوروف بر فرآيند تقسيم ميتوز اثركذار بوده و بىنظمىهاى كروموزومى را القاء كرد. بررسىها نشان داد كه بالاترين مقدار شاخص ميتوزى در شاهد و

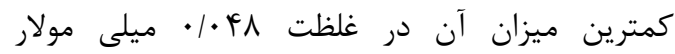

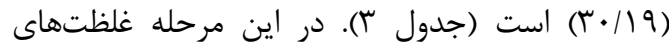

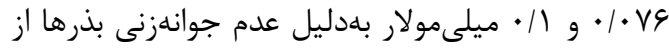
جدول حذف گرديد. همهنين كمترين و بيشترين تعداد كل سلولهاى در حال تقسيم در مراحل مختلف يروفاز،

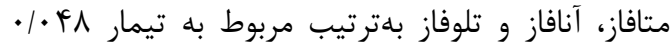


19/TV و r T/A قسمت (الف) در شكل I مشاهده مىشود سلولهاى سوماتيكى در مرحله متافاز طبيعى بوده است. در قسمت

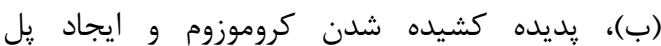
كروموزومى تا حدودى مشهود است. همرجنين در قسمت (ج) همين شكل تودهاى شدن كروموزومها در مرحله

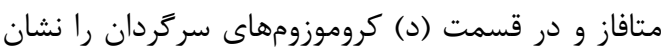

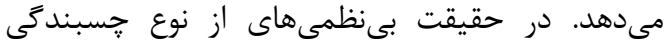
ممكن است بهدليل اثر گذارى تركيب فنلى حاصل از عصاره متانولى سوروف بر اسيدهاى نوكلئيك باشد كه موجب دى يلىمريزه شدن و انحلال بخشى از نوكلئويروتئينها، شكستن و تغييرات واحد كروماتيدى و لئي

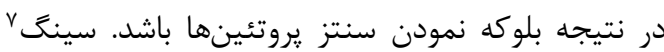

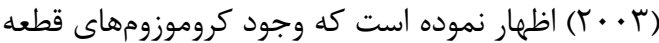
قطعه شده نشاندهنده شكستن كروموزومها و در نتيجه منجر به يُهاى كروموزومى در مرحله آنافاز و تلوفاز است. اين ناهنجارىهاى كروموزومى براى اثرات سمى بـى عصارههاى برى تلخ (Vernonia amygdalina) و آنازى (Gongronema latifolium) (نووكانما'و

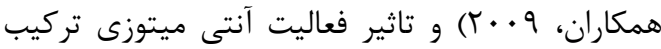
شيميايى ايزويروتون در جو (Hordeum vulgare) و يِياز (Allium cepa) كزارش شده است (بادر و

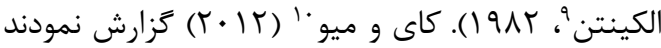
كه غلظتهاى بالاى عصاره برگ تاتوره ( Datura از تقسيم سلولى در نوك ريشه، طويل شدن و توسعه ريشه اوليه و جانبى، طول و تراكم ريشه جانبى سويا جلوگيرى نمود. همرجنين شاخص انحراف

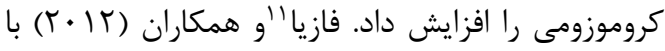

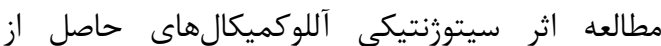

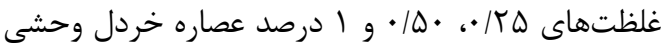
(Pisum sativum L.) بر نخود (Brassica nigra L.) كزارش نمودند كه عصاره خردل وحشى از تقسيم سلولى براسلى نخود جلوگيرى نمود و درصد ناهنجارىهاى كروموزومى در هر دو تقسيم سلولى ميتوز و ميوز افزايش يافت.

\footnotetext{
${ }^{7}$ Singh

${ }^{8}$ Nwakanma

${ }^{9} \mathrm{Badr}$ and Elkington

${ }^{10} \mathrm{Cai}$ and $\mathrm{Mu}$

${ }^{11}$ Fawzia
}

آللوكميكالهاى فنلها بهعلاوه تركيباتى نظير ترينها، استروئيدها، لاكتونها و اسيدهاى جرب با زنجيره

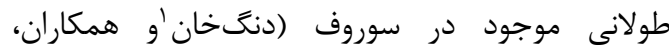
|| • (Y) بوده كه رشتههاى دوك ميتوزى را از فرم طبيعى خارج مىنمايند و در نتيجه موجب بهمزند استقرار ريزلولههاى سانترومرى و بدنبال آن هستههاى

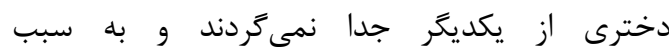
يلى يلوئيدى سلولها مىميرند. تيرركَو همكاران

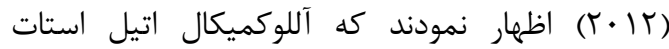
استخراج شده از برگهاى Aglaia odorata Lour از تقسيم ميتوزى يیاز (Allium cepa) جلوگيرى نمود و سبب ناهنجارىهاى ميتوزى در ريشه يِياز بلوسيله آسيب زدن به ساختمان كروماتين و دوك ميتوزى در ريشه معرض اين آللوكميكال شد. عبدو رئوف و سيديكو

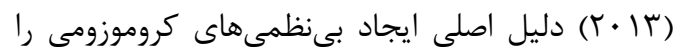

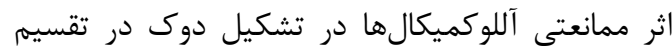
سلولى و ساماندهى كروماتينها بيان كردند. محمد و العشرى (T/ • ( ) نشان دادند كه افزايش غلظت عصاره آبى خردلسياه (Brassica nigra) از جوانهزنى نخود فرنكى ممانعت به عمل آورد. همجهنين ميزان تقسيم سلولى كاهش و درصد بىنظمىهاى كروموزومى در هر دو نوع تقسيم ميوز و ميتوز افزايش يافت. اثر غلظتهاى مختلف تركيب فنلى حاصل از عصاره متانولى علفهرز سوروف بر درصد و ايجاد انواع بىنظمىهاى كروموزومى همانطورى كه در جدول أ و

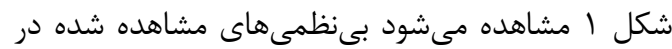

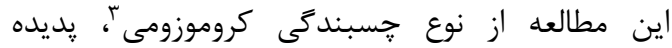

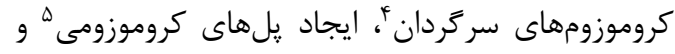

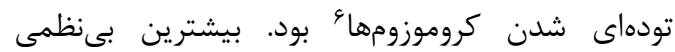
كروموزومى از نوع جسبند تُى و كروموزومهاى سرگردان

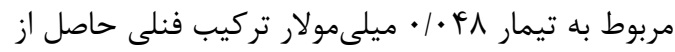

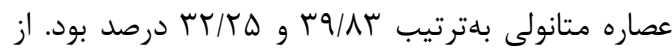
طرفى بيشترين يلهاى كرموزومى و تودهاى شدن بهن

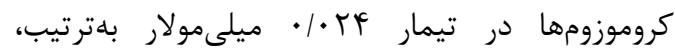

\footnotetext{
${ }^{1}$ Dang Khanh،

${ }^{2}$ Teerarak

${ }^{3}$ Stickness

${ }^{4}$ Laggard

${ }^{5}$ Bridges

${ }^{6}$ Clumping
} 
يلهاى كروموزومى بود. در مجموع با توجه به مشاهده

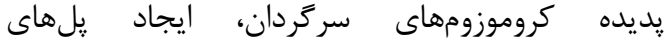
كروموزومى و تودهاى شدن كروموزومها در مريستم راسى ريشهجه برنج تحت تيمارهاى مختلف تركيب فنلى حاصل از عصاره متانولى سوروف ميىتوان نتيجهَيرى نمود كه اين تركيب مانع رفتار طبيعى ميتوزى سلول و آسيب به جوانهنى بذرهاى برنج شده

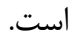

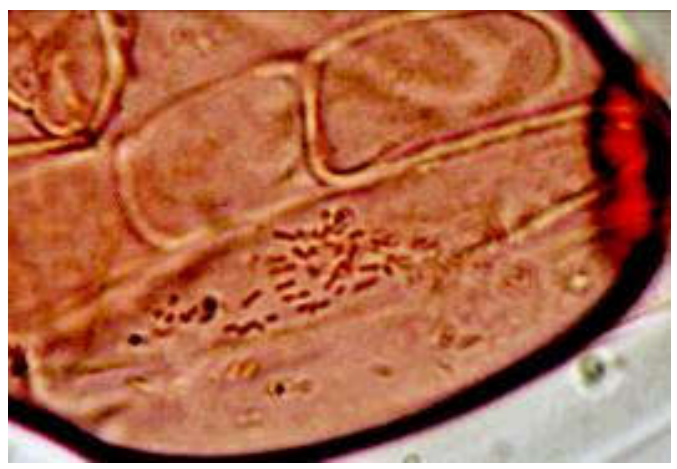

الف

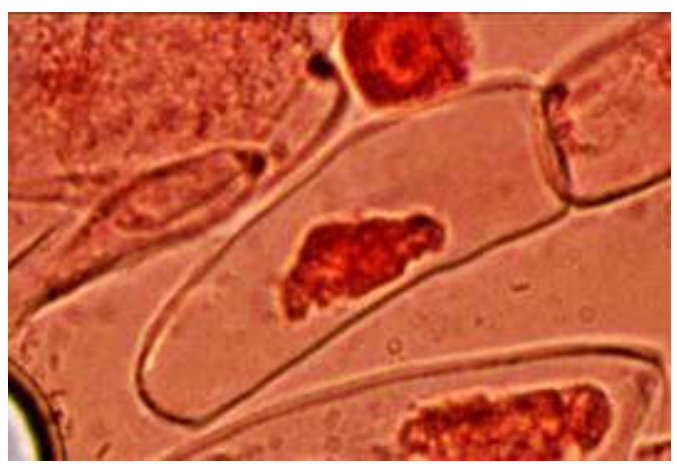

ج
كمترين و بيشترين اثر بازدارندگى بلهترتيب مربوط به

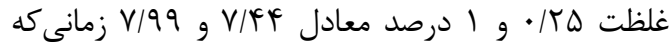
نخود براى ץ تا \& ماه انبار گرديد. همجنين درصد

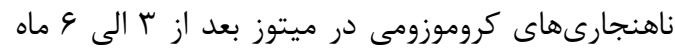

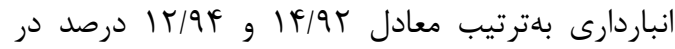

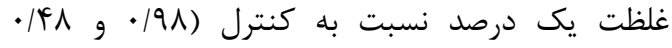

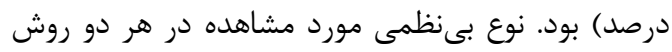

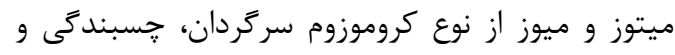

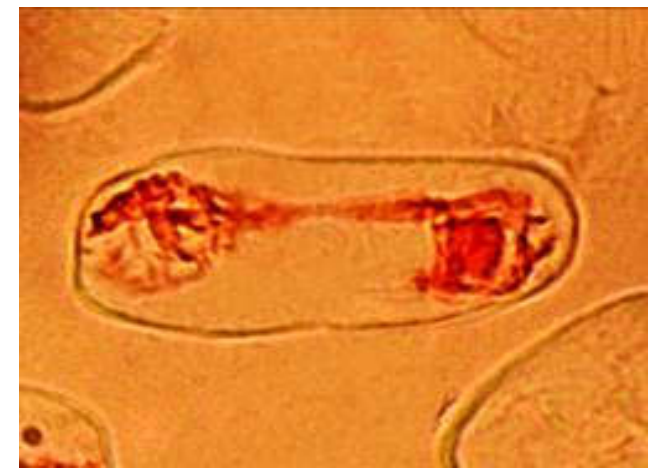

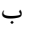

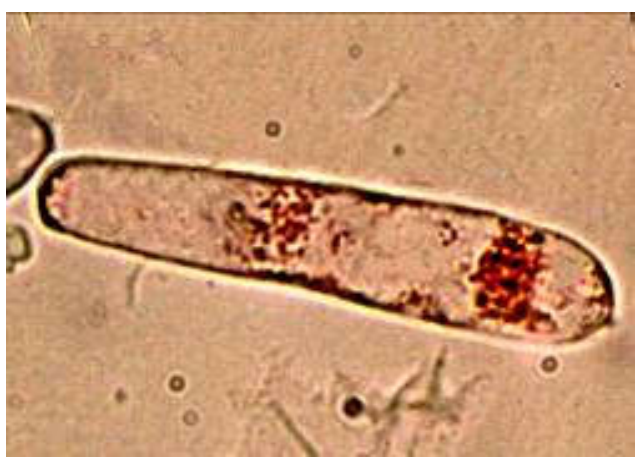

ง

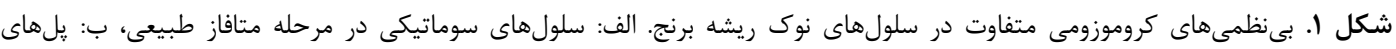

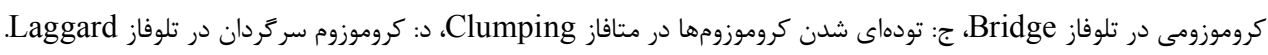

Fig. 1. Various chromosomal abnormalities in cells of rice root tip. A: somatic cells in the natural metaphase stage. B: bridge chromosome in telophase C: Clumping chromosomes in telophase D: laggard chromosome in telophase 


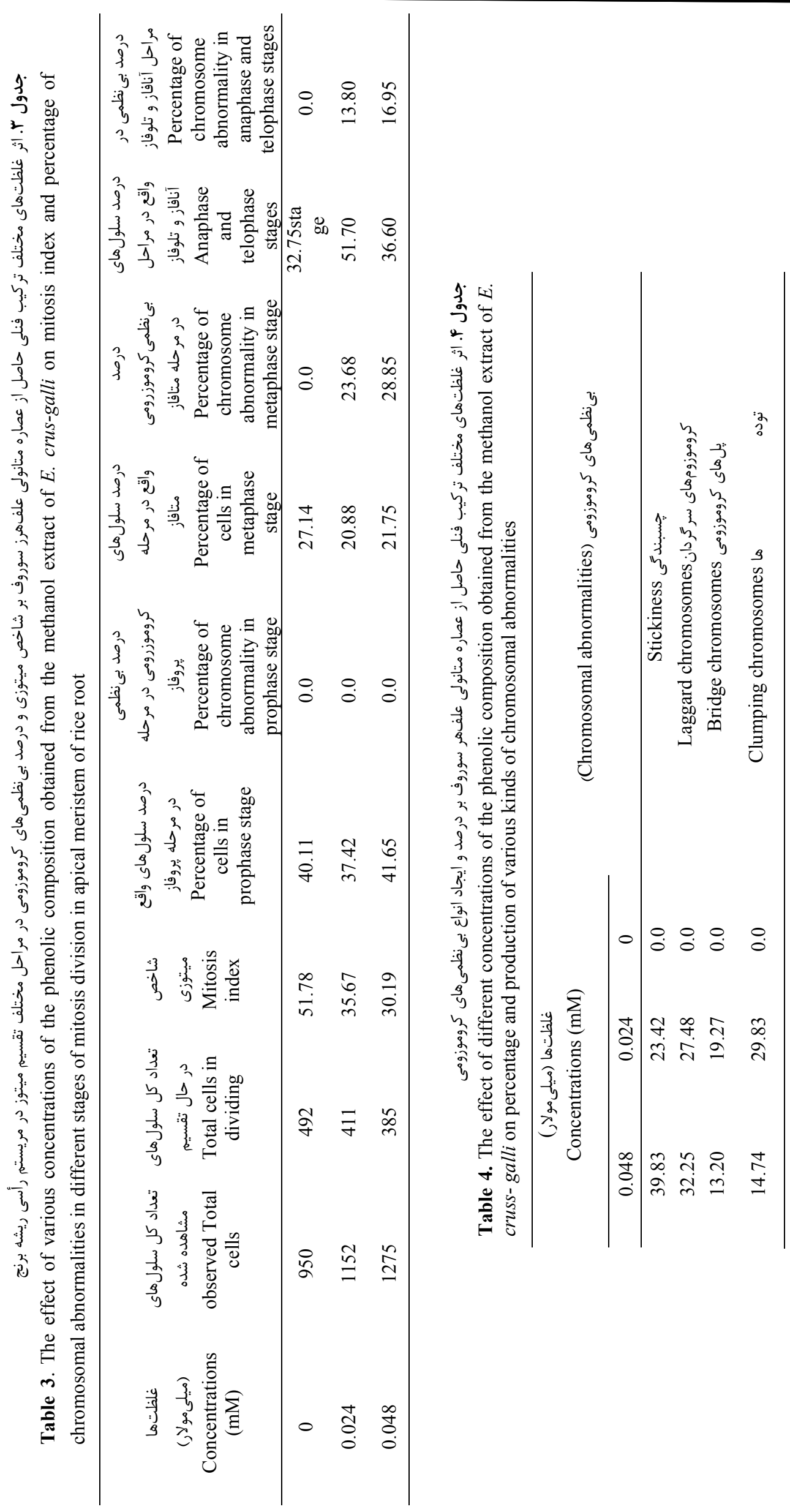




\begin{tabular}{|c|c|}
\hline در مراحل اوليه جوانهزنى و رشد است. اين امر نياز به & نتيجه كيرى \\
\hline دركى عميقتر از ساز و كارهاى مولكولى اين گونه اثرات & با توجه به مشاهده تاثير منفى تركيب فنلى حاصل \\
\hline دكرآسيب است كه ظهور و بروز آن بهصورت كاهش & از عصاره متانولى سوروف بر ميزان و كيفيت جوانهزنى و \\
\hline تقسيم ميتوز و افزايش بىنظمىهاى كروموزومى است. & رفتار ميتوزى برنج مىتوان اين گَونه نتيجه گيرى نمود \\
\hline در مجموع با توجه به زيست توده بالاو غالبيت علفهرز & كه در كشت مستقيم و يا نشايى برنج بايستى ميزان \\
\hline سوروف در مزارع برنج، جهت بهرهبردارى از تركيبات & بقاياى حاصل از علفهرز سوروف را به هر كونه ممكن \\
\hline دحرآسيب موجود در آن بر علفهاى هرز ديكر، نيازمند & در زمين مورد كاشت اين گياه مد نظر قرار داد. \\
\hline نوشيمى كامل تركيبات ثانويه اين علفهرز & همرجنين پيشنهاد ما كاشت ارقام مقاوم برنج به بقاياى \\
\hline 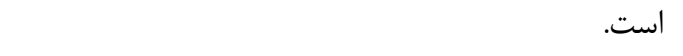 & ل اهرز سوروف، بهويزه \\
\hline
\end{tabular}

منابع

Abdul-Rauf, K.M. and Siddiqui, M.B. 2012. Allelopathic effect of aqueous extracts of different parts of Tinospora cordifolia (Willd.) Miers on some weed plants. Journal of Agricultural Extension and Rural Development, 4(6): 115-119. https://doi.org/10.5897/JAERD11.069

Abdul Rauf, K.M. and Siddiqui, M.B. 2013. Allelotoxic effect of parthenin on cytomorphology of broad bean (Vicia faba L.). Journal of the Saudi Society of Agricultural Sciences, 12: 143-146. https://doi.org/10.1016/j.jssas.2012.11.001

Azadbakht, A., Amraie, R., Mirzapour, S.R. and Nasrollahi, H. 2012. Effect of weed competition on growth characteristics of sunflower at different levels of nitrogen fertilizer. Annals of Biological Research, 3(11): 5162-5168.

Badr, A. and Elkington, T.T. 1982. Antimitotic and chromo toxic activities of Isoproturon in Allium cepa and Hordeum vulgare. Environmental and Experimental Botany, 22(3): 265-270. https://doi.org/10.1016/0098-8472(82)90017-X

Bakhshi Khaniki, Gh.R. 2010. Plant cytogenetic. Payam Noor Publisher. 402p. [In Persian]

Caceres, A. 2000. Calidad de la material prima para la elaboracion de productos fitofarma ceuticas. Primer Congreso International FITO 2000 "Por la investigacion, conservacion y diffusion del conocimiento de las plantas medicinal". 27-30 de septiembre, 2000, Lima, Peru.

Cai, S.L. and Mu, X.Q. 2012. Allelopathic potential of aqueous leaf extracts of Datura stramonium L. on seed germination, seedling growth and root anatomy of Glycine max (L.) Merrill. Allelopathy Journal, 30: 235-245.

Cruz-Ortega, R., Lara-Núñez, A. and Anaya, A.L. 2007. Allelochemical stress can trigger oxidative damage in receptor plants. Plant Signaling and Behavior, 2(4): 269-270. https://doi.org/10.4161/psb.2.4.3895

Dang Khanh, T., Huu Trung, K. and Hoang Anh, L.A. 2018. Allelopathy of Barnyardgrass (Echinochloa crus-galli) Weed: an Allelopathic Interaction with Rice (Oryza sativa). Vietnam Journal of Agricultural Sciences, 1(1): 97-116. https://doi.org/10.31817/vjas.2018.1.1.10

Davarynejad, G.H., Taghizadeh, S.F. and Asili, J. 2017. Effect of different solvents on total phenolic contents and antioxidant activity of Zizyphus jujube Miller fruits. Journal of Horticulture Science, 21(1): 158-166.

Einhellig, F.A. 2002. The physiology of allelochemical action: cluesand views. In: Reigosa, M.J., Pedrol, N. (eds.), Allelopathy, from Molecules to Ecosystems. Science Publishers, Enfield, New Hampshire. 
El-Shora, H.M. and Abd El- Gawad, A.M. 2015. Physiological and biochemical responses of Cucurbita pepo L. mediated by Portulaca oleracea L. allelopathy. Fresenius Environmental Bulletin, 24: 386-393.

Erdman, J.W., Balentine, D., Arab, L., Beecher, G., Dwyer, J.T., Folts, J., Harnly, J., Hollman, P., Keen, C.L., Mazza, G., Messina, M., Scalbert, A., Vita, J., Williamson, G. and Burrowes, J. 2007. Flavonoids and heart health: Proceedings of the ILSI North America flavonoids workshop. Nutrition, 137: 718-737. https://doi.org/10.1093/jn/137.3.718S

Erfani, E.R. 2002. Final report collection and knowledge weeds in rice field and current methods control in Mazandaran. Rice Research Institute of Mazandaran. [In Persian].

Fawzia, Mohamed, I. and Zeinab El-Ashry, M. 2012. Cytogenetic effect of allelochemicals Brassica nigra L. extracts on Pisum sativum L. World Applied Sciences Journal, 20(3): 344353.

Gabara, B., Kalwinek, J., KozirÓg, Z., Zakowska, Z. and Brycki, B. 2006. Influence of N, N-bis (3-aminopropylo) dodecyloamine on the ultra-structure of nuclei in Aspergillus niger mycelium and on cell proliferation and mitotic disturbances in Allium cepa L. root meristem. Acta Biologica Cracoviensia, Series Botanica, 48: 45-52.

Glin'ska, S., Bartczak, M., Oleksiak, S., Wolska, A., Gabara, B., Posmyk, M. and Janas, K. 2007. Effects of anthocyanin-rich extract from red cabbage leaves on meristematic cells of Allium cepa L. roots treated with heavy metals. Ecotoxicology and Environmental Safety, 68(3): 343350. https://doi.org/10.1016/j.ecoenv.2007.02.004

Haji Mehdipour, H., Khanavi, M., Shekarchi, M., Abedi, Z. and Pirali Hamedani, M. 2010. The determination of best extracting method of phenolic compounds in Echinacea angustifolia. Quarterly Journal of Medicinal Plants, 8(4): 32: 145-152. [In Persian with English Summary].

Hardgree, S.P. and Van Vactor, S.S. 2000. Germination and emergence of primed grass seeds under field and simulated-field temperature regimes. Annals of Botany, 85: 379-390. https://doi.org/10.1006/anbo.1999.1076

Hasanuzzaman, M., Ali, M. H. Alam, M.M., Akther, M. and Fakhrul Alam, K. 2009. Evaluation of pre-emergence herbicide and hand weeding on the weed control efficiency and performance of transplanted Aus rice. American-Eurasian Journal of Agronomy, 2(3): 138-143.

Heidarzade, A., Esmaeili, M. and Pirdashti, H. 2012. Common allelochemicals in root exudates of barnyardgrass (Echinochloa crussgalli L.) and inhibitory potential against rice (Oryza sativa) cultivars. International Research Journal of Applied Basic Science, 3(1): 11-17.

Kadiolu, I. and Yanar, Y. 2004. Alelopathic effect of plant extracts against seed germination of some weeds. Asian Journal of Plant Sciences, 3(4): 472-475. https://doi.org/10.3923/ajps.2004.472.475

Kazemi, M., Roshandel, P. and Rafiei Al- Hosseini, M. 2017. Evaluation of allelopathic potential of six medicinal plants on some physiological and biochemical characteristics of Beta vulgaris and its two important weeds. Journal of Plant Production and Function, 6: 65-80.

Khorasani Nezhad, S., Galeshi, A.K. and Fakhr Tabatabaie, S.M. 2009. Study of allelopathic potential of various organ extract of cucumber on seedling growth indices of cucumber, tomato, pepper and basil. Journal of Iranian Horticultural Sciences, 40(1): 55-60. [In Persian with English Summary].

Kohli, R.K., Singh, H.P., and Batish, D.R. 2001. Allelopathy in agroecosystems. Food Products Press, USA, $447 \mathrm{p}$.

Maguire, J.D. 1962. Speed of germination- aid selection and evaluation for seedling emergence and vigor. Crop Science, $\quad 2: \quad 176-177$. https://doi.org/10.2135/cropsci1962.0011183X000200020033x 
Malick, C.P. and Singh, M.B. 1980. In plant enzymology and histo enzymologhy. Kalyani Publishers, New Dehli.

Mighani, F. 2003. Allelopathy. Partov-e- Vagheeh Publications, 256p. [In Persian].

Mishra, A. 2015. Allelopathic properties of Lantana camara. Lnt. International Research Journal of Basic and Clinical Studies, 3: 13-28.

Mohamed, F.I. and El-Ashery, Z.M. 2012. Cytogenetic effect of allelochemicals of Brassica nigra extract on Pisum sativum. World Applied Sciences Journal, 20(3): 344-353.

Mohammadzadeh, M., Peighambari, S.A., Nabipoor, A.R. and Norouzi, M. 2009. Evaluation of rice genotypes response to salinity stress at seedling stage in hydroponic culture. Journal of Crop Breeding, 1(2): 85-95. [In Persian with English Summary].

Monica, F., Josekna, A., Sillero, C. and Rubiales, D. 2007. Intercropping with cereals reduces infection by Orobanche crenata in legumes. Crop Protection, 26(8): 166-1672. https://doi.org/10.1016/j.cropro.2006.10.012

Nwakanma, N.M.C., Odeigah, P.G.C. and Oboh, B.O. 2009. Genotoxic effects of Gongronema latifolium and Vernonia amygdalina using the Allium test. In: Book of Proceedings, 4th UNILAG Conference and Fair, Nigeria, 21-22 October, 2009, pp: 81-90.

Oksman-Caldentey, K.M. and Inzé, D. 2004. Plant cell factories in the post-genomic era: new ways to produce designer secondary metabolites. Trends in Plant Science, 9(9): 433-440. https://doi.org/10.1016/j.tplants.2004.07.006

Omidbeigi, R. 2009. Production and processing of medicinal plants. Astan Ghods Razavi publisher. 47-182p. [In Persian].

Pandey, S. and Velasco, L. 2005. Trends in crop establishment methods in Asia and research issues. In: Rice is Life Scientific Perspectives for the 21st Century. Toriyama, K., Heong, K.L., Hardy, B. (eds.). International Rice Research Instituteand Tsukuba, Japan International Research Center for Agricultural Sciences, Los Ba nos, Philippines, pp: 178-181.

Regosa, M., and Pedrol, N. 2002. Allelopathy from molecules to ecosystems. Science publishers Gnc. NH. USA. P 12- 195.

Rho, B.J. and Kil, B.S. 1986. Influence of phytotoxin Pinus rigida on the selected plants. Journal of Natural Science, Wonkwang University, 5: 19-27.

Rodenburg, J. and Demont, M. 2009. Potential of herbicide-resistant rice technologies for subsaharan Africa. Journal of Agrobiotechnology Management and Economics, 12(3-4): 313-325.

Sathis Kumar, D., Banji, D., Harani, A., Tirupathi Rao, A., Nageswar Rao, S., Pavan Kumar, CH. and Santhi Krupa, D. 2013. Screening of polyphenolic compounds in Echinochloa crusgalli Roxb extracts by various analytical techniques. Asian Journal of Chemistry, 25(17): 98489852. https://doi.org/10.14233/ajchem.2013.15505

Setia, N., Batish, D.R., Singh, H.P. and Kohli, R.K. 2007. Phytotoxicity of volatile oil from Eucalyptus citriodora against some weedy species. Journal of Environmental Biology, 28: 6366.

Sheidai, M., Habibi, M., Azizain, D. and Khatamsaz, M. 2009. Cytology and palynology of the Clematis L. species (Ranunculaceae) in Iran. Acta Botanica Croatica, 68(1): 67-77.

Singh, R.J. 2003. Plant cytogenetic. CRC Press, image dueing cell cycle in Allium cepa and Vicia boca Raton, pp: 463.

Soltani, A. and Torabi, B. 2014. Design and analysis of agricultural experiments (with SAS programs). Jehad Daneshgahi Mashhad Press, Mashhad, Iran. 431p. [In Persian]. 
Teerarak, M., Charoenying, P. and Laosinwattana C. 2012. Physiological and cellular mechanisms of natural herbicide resource from Aglaia odorata Lour. on bioassay plants. Acta Physiologiae Plantarum, 34(4): 1277-1285. https://doi.org/10.1007/s11738-011-0923-5

Teerarak, M., Laosinwattana, C. and Charoeying, P. 2010. Evaluation of allelopathic, decomposition and cytogenetic activities of Jasminum officinale L. f. var. grandiflorum (L.) Kob. on bioassay plants. Bioresource Technology, 101: 5677-5684. https://doi.org/10.1016/j.biortech.2010.02.038

Yang, C.M., Lee, C.N. and Chou, C.H. 2002. Effects of three allelopathic phenolics on chlorophyll accumulation of rice (Oryza sativa) seedlings: I. Inhibition of supply orientation. Botanical Bulletin of Academia Sinica, 43: 299-304. 


\title{
Research Article \\ Studying the Hetrotoxicity Potential of the Phenolic Composition Obtained from the Methanolic Extract of Echinochola crus-galli Weed on Germination Traits and Cytogenetic Behavior of Rice
}

\author{
Ebrahim Gholamalipour Alamdari ${ }^{1, ~}{ }^{*}$, Amir Ghorbani ${ }^{2}$, Hossein Sabouri ${ }^{3}$, Meisam Habibi ${ }^{4}$ \\ Extended abstract
}

Introduction: Without a doubt, plant hetrotoxicity is one of the important factors in determining the distribution and abundance of some species in plant communities. Thus, the purpose of this experiment was to evaluate the effect of phenolic composition obtained from the methanol extract of Echinochola crus-galli on germination traits and cytogenetic behavior of rice.

Materials and methods: This experiment was done to assess hetrotoxic potential of various concentrations $(0,0.024,0.048,0.076$ and $0.1 \mathrm{mM})$ of the phenolic composition obtained from the methanol extract of whole-organ of E. crus-galli on germination traits of rice as well as mitosis division of meristematic cells of radicle in a completely randomized design. To extract thephenolic composition, warm extraction method using a methanol solvent was used. For studying mitosis division, first rice seeds were germinated. Then, each of the steps such as fixation, hydrolysis, staining, squashing and microscopic studies were done on the end of the radicle. Mitosis indices and percentage of mitosis inhibition were calculated and also percentage of each of chromosomal abnormalities at four stages of prophase, metaphase, anaphase and telophase as compared to total cells was calculated.

Results: The lowest percentage and rate of germination and relative germination were found in two concentrations of the 0.076 and $0.1 \mathrm{mM}$ of phenolic composition of E.crus-galli, so that no germination was observed in these treatments. In this study, mitosis division was normal in control samples, so that the rice plant included 12 chromosomes in the metaphase stage. Also the chromosomes were normal in the telophase stage and chromosomal abnormalities were not observed in meristem cells of radicle tip of the control. The lowest value of mitosis indices and the number of dividing cells were related to the concentration of 0.048 $\mathrm{mM}$ wuth 30.19 and 385 cells, respectively. In the present study, chromosomal abnormalities in the stages of metaphase, anaphase and telophase were increased with increasing concentration of phenolic composition, and were 28.85 and $16.95 \%$ in $0.048 \mathrm{mM}$ concentration of phenolic composition, respectively. The most chromosomal abnormalities were of sticky and laggard type, which were related to the concentration of 0.048 $\mathrm{mM}$ of phenolic composition with 39.83 and $32.25 \%$, respectively. The highest number of chromosomal bridges and clumping were obtained in $0.024 \mathrm{mM}$ of phenolic composition with about 19.27 and $29.83 \%$, respectively.

Conclusion: In this study, phenolic composition obtained from the methanol extract of E. crus-galli had asignificant inhibitory effect on germination traits and mitosis division in root tip cells of rice. Thus, the amount of E. crus-galli residues in the field should be considered in direct and indirect cultivation of rice.

Keywords: Bridge chromosomes, Chromosomal abnormalities Phenolic composition, Relative germination percentage

\section{Highlights:}

1-Difference in impact of the phenolic composition obtained from the methanol extract of Echinochola crus-galli on germination and reduced cytogenetic behavior of rice is related to their threshold concentration.

2- It is advised to cultivate varieties of rice resistant to the remnants of harmful compounds of E. crusgalli as direct cultivation or under nursery condition.

\footnotetext{
1 Assistance Professor of Plant Production Department, College of Agriculture and Natural Resources, Gonbad Kavous University, Gonbad Kavous, Iran

${ }^{2}$ Graduated student of Identification and Weeds Control branch, College of Agriculture and Natural Resources, Gonbad Kavous University, Iran

3 Associate Professor of Plant Production Department, College of Agriculture and Natural Resources, Gonbad Kavous University, Iran

${ }^{4}$ Instructor of Biology Department, College of Basic Science of Gonbad Kavous University, Iran

${ }^{*}$ Corresponding author, E-mail: eg.alamdari@gonbad.ac.ir
}

http://dorl.net/dor/20.1001.1.23831251.1399.7.1.8.5

http://dx.doi.org/10.29252/yujs.7.1.67

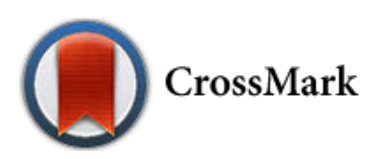

